\title{
Mammal and butterfly species richness in Chile: taxonomic covariation and history
}

\author{
Riqueza de mamíferos y mariposas en Chile: covariación taxonómica e historia
}

\author{
HORACIO SAMANIEGO ${ }^{1,2,{ }^{*}}$ \& PABLO A. MARQUET ${ }^{3,4,5,6}$ \\ ${ }^{1}$ Department of Biology, University of New Mexico, USA \\ ${ }^{2}$ Instituto de Silvicultura, Universidad Austral de Chile, Casilla 567, Valdivia, Chile \\ ${ }^{3}$ Departamento de Ecología Pontificia Universidad Católica de Chile, Alameda 340, C.P. 6513677, Casilla 114-D, \\ Santiago Chile \\ ${ }^{4}$ Center for Advanced Studies in Ecology and Biodiversity (CASEB) \\ ${ }^{5}$ Institute of Ecology and Biodiversity (IEB), Casilla 653, Santiago, Chile \\ ${ }^{6}$ National Center for Ecological Analysis and Synthesis (NCEAS), 735 State Street, suite 300, Santa Barbara, \\ California 93101-5504, USA \\ *e-mail for correspondence: horacio.samaniego@gmail.com
}

\begin{abstract}
Understanding species richness spatial distribution is of fundamental importance to face the current biodiversity crisis that affects biotas around the world. Taxonomical covariation in species occurrence may offer the possibility to identify common factors that restrict species richness, as well as some guidelines to the identification of key areas for conservation purposes. To this aim, we analyze the geographic distribution of mammals and butterflies in Chile using $0.5^{\circ}$ latitude and longitude quadrats. We found that, for both taxa, there is a strong bell-shaped latitudinal gradient in species richness with a peak at mid-latitudes $\left(33-43^{\circ} \mathrm{S}\right)$. The results from multiple stepwise regression analysis shows that for both taxa productivity measured using the Normalized Difference Vegetation Index (NDVI) is the most important variable driving changes in species richness followed by glaciation and elevation depending on the taxa. Mid-domain effects were either weak or unimportant in affecting the richness pattern. Variance partitioning analysis shows that the spatial components alone are irrelevant to the richness pattern. We show that spatial covariation in richness of butterflies and mammals, is strongly influenced by spatial scale, possibly as the result of a scale-dependent effects on individual species ranges, whereas factors related to specific ecological characteristics, are more important at smaller scales. Because richness gradients are ultimately the product of speciation and colonization processes on longer time scales, we propose that species richness gradients in Chile may be explained by the interaction between historical processes associated to desertification and glaciation together with productivity. The former sets the domain within which productivity produces a similar richness pattern for both taxa despite their different phylogenetic histories and physiological requirements.
\end{abstract}

Key words: lepidoptera, mammalia, Chile, latitudinal gradient, species richness.

\section{RESUMEN}

Comprender la distribución espacial de la riqueza de especies es un aspecto de fundamental importancia para enfrentar la actual crisis que afecta a las biotas del mundo. En este sentido, el estudio de la covariación taxonómica en el espacio nos da la posibilidad de identificar factores comunes que restringen la riqueza, además de ofrecer una oportunidad para identificar áreas claves para la conservación. Con este propósito, analizamos la distribución geográfica de mamíferos y mariposas en Chile usando cuadrículas de $0,5^{\circ}$ de latitud y longitud. Para ambos taxa, existe una distribución latitudinal unimodal con un máximo de riqueza a latitudes intermedias $\left(33-43^{\circ} \mathrm{S}\right)$. Usando una regresión múltiple paso a paso mostramos que la productividad es el factor gravitante para explicar la riqueza de ambos taxones seguido por efectos asociados a glaciaciones y elevación según sea el taxa. Efectos asociados al dominio medio muestran ser débiles o no significantes para determinar la distribución latitudinal de la riqueza en Chile. Un ánalisis de partición de varianza muestra que componentes exclusivamente espaciales son también irrelevantes para explicar el patrón de riqueza. Mostramos que la covariación entre la riqueza de mariposas y mamíferos está fuertemente influenciada por la escala espacial, posiblemente producto de efectos que actúan sobre los rangos de distribución a distintas escalas, mientras que factores relacionados con características ecológicas son más importantes a escalas pequeñas. Debido a que los gradientes de riqueza son en último término producto de procesos de especiación 
y colonización, proponemos que la riqueza de especies en Chile podría explicarse por la interacción entre procesos históricos asociados con desertificación y glaciación junto a procesos relacionados con la productividad. En este contexto, procesos históricos determinarían el dominio en que factores asociados a la productividad condicionan el patrón de riqueza para ambos taxones a pesar de estos tener historias filogenéticas y requerimientos fisiológicos distintos.

Palabras clave: lepidoptera, mammalia, Chile, gradiente latitudinal, riqueza de especies.

\section{INTRODUCTION}

Under the present burgeoning human alteration of earth's ecosystems and the associated biodiversity crisis, the need to quantify the levels and distribution of biodiversity, and to improve our understanding of the processes underlying its generation, distribution and maintenance, has become a fundamental issue (Gaston 2000). The analysis of macroecological patterns of distribution and spatial covariation in diversity among taxa have important theoretical and practical implications ranging from the identification of common causal factors underlying the spatial variation in biodiversity to the design of reserve networks. Ecologists have been describing and analyzing patterns in biological diversity across time and space for more than three decades (e.g., Wilson 1974, Rapoport 1975, Rosenzweig 1995, Brown \& Lomolino 1998). However, no consensus has been reached regarding the mechanisms responsible for generating and maintaining biodiversity gradients at large spatial scales (Shmida \& Wilson 1985, Currie \& Paquin 1987, Rohde 1992, Kerr \& Packer 1997, Rosenzweig \& Sandlin 1997, Colwell \& Lees 2000, Hortal et al. 2008). It is becoming increasingly clear that biodiversity patterns are of multivariate nature such that no one factor will, by itself, explains the variability in species richness. The final cause seems to be hidden in the interaction among the physiological and ecological characteristics of species, and the pattern of variability in the abiotic and biotic environment in which they are, and have been, embedded (Currie \& Paquin 1987, Latham \& Ricklefs 1993, Kerr \& Packer 1997, Kerr et al. 1998, Kerr \& Currie 1999, Kerr \& Packer 1999, Gaston 2000, Marquet et al. 2004).

One way of improving our understanding of the factors determining variation in biodiversity is to analyze patterns in species diversity for taxonomically, physiologically, and ecologically distinct taxa within a similar area. The few studies that have looked into this issue report that when correlations are found these are usually weak and vary in strength with the scale of analysis (Gaston 1996, Bokma et al. 2001, Jetz \& Rahbek 2001, 2002, van Rensburg et al. 2002). Covariation has been explained by a shared latitudinal effect (Pearson \& Cassola 1992, Flather et al. 1997), however, since latitude per se does not affect species richness, the pattern remains largely unexplained. Additionally, covariation becomes weaker when the analysis focuses on areas of high richness among different taxa (Prendergast et al. 1993, Dobson et al. 1997, van Jaarsveld et al. 1998, Wessels et al. 1999), which further complicates the design of preserve networks (Pressey et al. 1993, Vane-Wright 1996, Cofré \& Marquet 1999, Tognelli et al. 2008).

In this paper we assess the spatial covariation in species richness between two distantly related taxa: mammals and butterflies in Chile. This country provides a good testing ground to evaluate the hypotheses pointed out above. This is mainly due to: (1) its wide latitudinal range with strong gradients in abiotic conditions, (2) its long history of isolation from the rest of the Neotropics caused by major geographic barriers (the Pacific Ocean to the west, the dry Atacama desert in the north and the Andes mountain to the east, Cabrera \& Willink 1973, Marquet 1994, Villagrán \& Hinojosa 1997, Armesto et al. 1998, Marquet et al. 1998, Ruggiero et al. 1998), and (3) a well documented and active Quaternary glacial history (Hollin \& Schilling 1981, Clapperton 1994) that caused country wide changes in climatic conditions acting as a strong environmental forcing that affected all of its biota (Villagrán \& Hinojosa 1997, Latorre et al. 2007). Considering these attributes, it seems plausible to hypothesize that at the scale of the whole country, diversity patterns should be highly covariant among taxa because of a shared history of environmental 
fluctuations through time linked to glaciations in southern Chile and desertification in the north. Furthermore, we hypothesize that the strength of the pattern of spatial covariation should vary across space becoming weaker as the spatial scale of analysis is reduced, because of the increasing importance of local idiosyncratic conditions that might disrupt richness covariation. Thus, at an ecoregional scale, we expect to find a weak covariation in species richness. We tested these hypotheses using distribution (extent of occurrence) data on butterfly and mammal richness at two spatial scales (country and ecoregion).

\section{MATERIAL AND METHODS}

\section{Species distribution data}

To analyze the geographic distribution of species richness, we divided the country in half-degree quadrats employing a Geographic Information System. Only quadrats that had at least $75 \%$ of their area as emerged land were used to minimize the oceanic influence. This method has been widely used in ecological studies to map species diversity (Wilson 1974, McCoy \& Connor 1980, Arita et al. 1990, 1997, Ceballos \& Navarro 1991, Willig \& Sandlin 1991, Kerr \& Packer 1997, Tognelli \& Kelt 2004). Species incidence on each of these quadrats was estimated by recording species' presence or absence using geographic distribution maps collected from the literature (Mann 1978, Redford \& Eisenberg 1992, Kelt \& Gallardo 1994, Medel et al. 1990, Spotorno et al. 1994, Wilson \& Reeder 2005 for mammals, Peña \& Ugarte 1996, Shapiro 1997, Concha-Bloomfield \& Parra 2007 for butterflies). To minimize biases associated with uncertainty in range boundaries, we used a conservative criterion to register the presence of a species in a quadrat. The geographic distribution of each species was required to overlap at least $75 \%$ of the quadrat area in order to be recorded as present. We repeated all analyses using the mean richness per latitudinal band. This procedure avoids comparing latitudinal bands with different number of quadrats, which would lead to inaccuracies related to the species-area structure of latitudinal bands (Romdal et al. 2005).
Environmental determinants of species richness data

Simple correlation analyses were used to evaluate covariation of species richness between mammals and butterflies. We then used multiple regression analyzes to understand if the observed correlation, or lack of thereof, is the result of the shared influence of some environmental drivers. To such aim, five abiotic variables were considered into a multiple stepwise regression model: the normalized difference vegetation index (NDVI), the mean elevation (ELEV), the mean daily temperature (TEMP), precipitation (PP), the number of vegetation types (VEG), latitude (LAT), and glaciation (GLA) in each quadrat. Values for each of these variables within each half-degree quadrat were considered. All these variables are used as surrogates for different factors that have been proposed to affect species richness. NDVI is an indicator of green biomass and primary productivity (Fjeldsa et al. 1997, Oesterheld et al. 1998, Hurlbert \& Haskell 2003, Kerr \& Ostrovsky 2003). Mean NDVI value from April 1992 to March 1993 (Smith et al. 1997 available at http://edcdaac.usgs.gov/1KM/ $1 \mathrm{kmhomepage.html)}$ is a surrogate for available energy, as it accounts for the amount of greenness and is know to be highly correlated to potential evapotranspiration and actual evapotranspiration (Box et al. 1989). ELEV (available at http://edcaac.usgs.gov) was included to account for the strong altitudinal gradient in Chile and to control for its effects (Stevens 1992, Rahbek 1997). VEG captures the level of landscape heterogeneity in terms of the different landscape units perceived by species (Rabinovich \& Rapoport 1975, Nichols et al. 1998) and was obtained by counting the number of vegetation types in each quadrat, following the vegetation atlas of Chile (Gajardo 1994). PP and TEMP account for the physiological restrictions to species occurrence (Root 1988) and were compiled from the 1961-1990 database (available at the IPCC Data Distribution Center http:// ddcweb1.cru.uea.ac.uk/). We additionally included latitude (LAT) and glaciation in multiple regression analyzes. The former variable accounts for those factors that, while varying with latitude, have not been included 
in the analysis. Glaciation was accounted for by tagging each quadrat based on the amount of overlap with the last glacial cover as mapped by Hollin \& Schilling (1981). The same criterion employed to estimate species incidence per quadrat was used to determine if a quadrat had been glaciated. GLA was then entered as a binary variable into the model (see below) to account for the fact that, especially in southeastern Chile, a large fraction of the territory was covered by ice during the last glacial maxima (Clapperton 1994), which might have affected the colonization/extinction dynamics of these areas (e.g., Hawkins \& Porter 2003b), and thus the contemporary richness patterns (see also Cofré et al. 2007).

\section{Correlation and regression analysis}

Simple pairwise correlations were used to gain a general understanding on how each variable relates to species richness. After this exploratory analysis we used a multiple stepwise regression model, to describe how environmental variables explain species richness variability. We standardized each variable in order to compare the weight of each independent variable in the selected model. Both, backward and forward elimination was used in the multiple regression procedure, in conjunction with the Akaike information criteria, which penalizes more complicated models for the inclusion of more variables (Venables \& Ripley 2002). We carried out this procedure using $0.5^{\circ}$ latitude longitude quadrats and also using mean richness values per latitudinal band. This later analysis allowed us to assess the effect of geometric constraints on species richness (see below).

\section{Geometric constraint analysis}

We also checked for the existence of a potential mid-domain effect (MDE, Colwell \& Hurtt 1994). MDE has been considered a null model that accounts for geometric contraints to species occurrence imposed by abrupt changes in biotic and/or abiotic variables (but see Zapata et al. 2003, Colwell et al. 2005, Hawkins et al. 2005, Rangel \& Diniz-Filho 2005, Kerr et al. 2006, McClain et al. 2007). We used a one dimension framework to evaluate MDE by looking at species richness per latitudinal bands. MDE predictions were computed by considering only those species whose northern latitudinal ranges lie south of the Chile/Peru border $\left(17^{\circ} \mathrm{S}\right)$. Random midpoints from the empirical species range frequency distribution (Colwell \& Lees 2000) were used to feed a Monte Carlo simulation with 5,000 replicates as implemented by McCain (2005).

\section{Variance partitioning}

Following Borcard et al. (1992), we partitioned species richness, of our full set of quadrats, in four components of variation: (a) non-spatial environmental component, (b) spatially structured environmental component, (c) nonenvironmental spatial component, and (d) unexplained. The spatial component of species richness $(b+c)$ corresponds to the spatial structuring of the environmental variables (e.g., spatial autocorrelation). The portion of variability explained by each component was assessed using the coefficient of determination, $r^{2}$, of the best model resulting of using a stepwise regression procedure with a thirdorder polynomial as input model (Legendre 1993). The selected model to evaluate the effect of components $(b+c)$ was:

$\hat{z}=b_{0}+b_{1} x+b_{2} y+b_{3} x^{2}+b_{4} y^{2}+b_{5} x y^{2}+b_{6} x^{3}+b_{7} y^{3}$,

where $\hat{z}$ is species richness, $x$ is latitude, and $y$ represents longitude.

The $r^{2}$ resulting from regressing species richness on the environmental variables selected in previous multiple regression analysis, represents the proportion of variability explained by the non-spatial environmental component and spatially structured environmental component $(a+b)$.

The resulting $r^{2}$ from the regression of species richness on both environmental variables and spatial variables quantifies the proportion of variability in species richness that is explained by the environmental and spatial variables $(a+b+c)$. This quantity will help us to obtain the unexplained component $(d=1-$ $(a+b+c))$. Finally, the contribution of each component is calculated as $b=(a+b)+(b+$ $c)-(a+b+c) ; a=(a+b)-b ; c=(b+c)-$ $b$ (Legendre \& Legendre 1998, but see Lobo et al. 2002 for other examples). 
Environmental determinants by ecoregion

In order to test the hypothesis of a reduction in the strength of covariation at the ecoregion level, we repeated the multiple regression analysis for five different ecoregions that encompass the bioclimatological regions of Chile (Hajek \& Di Castri 1975). The northern area was divided in two ecoregions: (1) the Atacama desert, one of the driest desert on earth with high thermal oscillation, and (2) Puna, which corresponds to the adjacent highlands of the Atacama desert (above 2,000 $\mathrm{m}$ of altitude), with a cold arid climate and summer precipitation. The selection of the southernmost boundary for the Puna area was set at $27^{\circ}$, where the high altitude plateau ends and an intrusion toward higher elevation of the Atacama Desert occurs (Marquet 1994, Moreno et al. 1994). In central Chile we distinguished (3) the central Mediterranean zone $\left(27-35^{\circ} \mathrm{S}\right)$. This area has been recognized as a truly endemic ecoregion restricted to the Chilean territory in the Neotropics (Arroyo 1994, Myers et al. 2000). Finally, towards the southernmost part of the country we distinguished (4) temperate forest dominated by mixed Nothofagus forest (35-44 $\mathrm{S}$ latitude, Armesto et al. 1995), and (5) the subantarctic forest and Patagonian steppe $\left(44-55^{\circ} \mathrm{S}\right.$ latitude), dominated by extensive Nothofagus pumilio (Poepp. \& Endl.) Krass forest and grasslands.

\section{RESULTS}

\section{Richness distribution and latitudinal patterns}

Species richness is a peaked function of latitude (Fig. 1). There is a strong decline in richness of both taxa from latitudes 18 to $27^{\circ}$ $S$ then a steep increase occurs until approximately $37^{\circ} \mathrm{S}$, followed by a decrease in richness until $50^{\circ} \mathrm{S}$. For mammals two

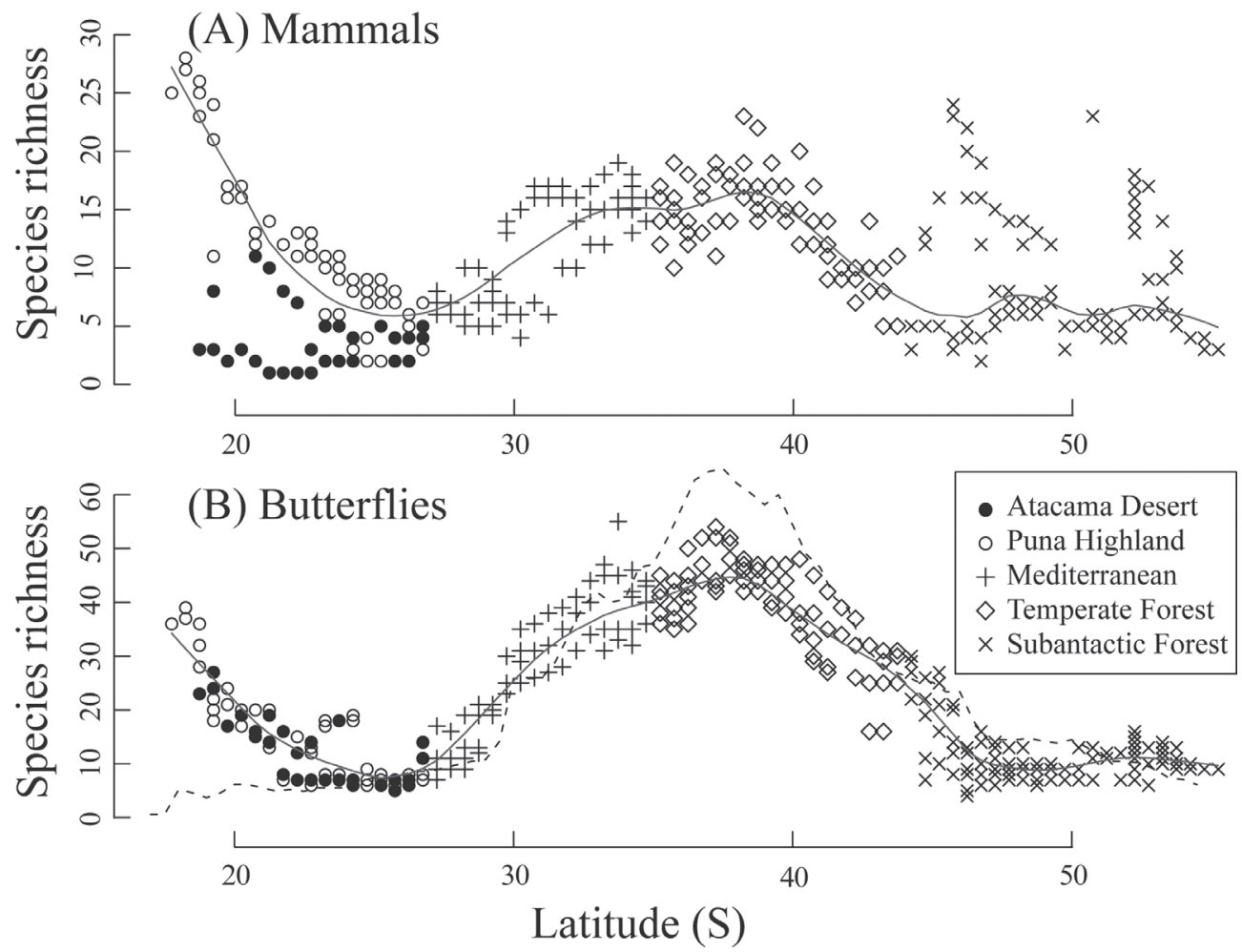

Fig. 1: Latitudinal distribution of species richness by macrobiome. Plant species richness from Villagrán \& Hinojosa (1997) is shown as a dotted line; the lowess curve is shown for visual purposes only.

Distribución latitudinal de la riqueza de especies por ecorregión. Riqueza de plantas es mostrada en línea punteada según Villagrán \& Hinojosa (1997); la curva tipo lowess se muestra solo para efectos visuales. 
areas of high richness in the subantarctic forest ecoregion punctuates this decrease. The distribution of species richness within the country is shown in Fig. 2. Two areas of high richness exist in butterfly richness, one of them in the Puna highland (34+ species at $18^{\circ}$ $\mathrm{S})$ and the second -and most conspicuous- in the south/central area, at the transition between the Mediterranean and temperate forest $\left(49+\right.$ species at $\left.37^{\circ} \mathrm{S}\right)$. The distribution of mammal richness shows at least three centers of high species diversity. The maximum richness (29 species) is located in the highlands $\left(18^{\circ} \mathrm{S}\right)$. The second highest richness zone (28 species) corresponds to the area of the Torres del Paine National Park $\left(51^{\circ} 30^{\prime} \mathrm{S}\right)$, an area of confluence of three main vegetation types, the temperate forest, the subantarctic forest and Patagonian steppe. Finally, the third area of high richness (25 species) is at the Alto Biobío area (3730' S).

\section{Taxonomic covariation}

There is a striking similarity in the latitudinal richness pattern in both taxa (Fig. 1). This is reflected in a high and significant correlation between mammal and butterfly richness per latitudinal bands (Pearson's $\mathrm{r}=0.78, \mathrm{P}<$ $0.0001, \mathrm{n}=74)$. However, the correlation

\section{Butterflies}

\section{Mammals}

\section{Species Number}

\begin{tabular}{r|l|}
$4-11$ & $1-4$ \\
\hline $12-18$ & $5-8$ \\
\hline $19-25$ & $9-12$ \\
\hline $26-33$ & $13-16$ \\
\hline $34-40$ & $17-20$ \\
\hline $41-47$ & $21-24$ \\
$48-55$ & $25-29$
\end{tabular}

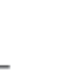

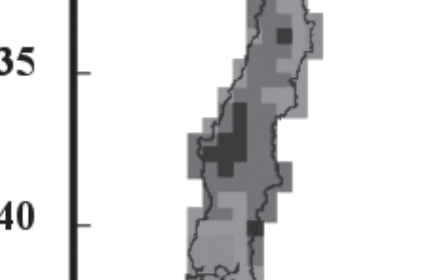

45

50

$55 \mathrm{~S}$
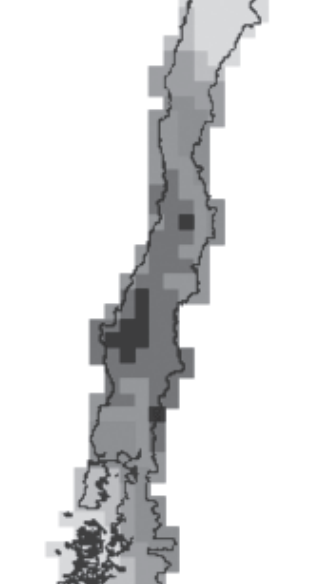
diminishes on a quadrat-base at the country level $(\mathrm{r}=0.55, \mathrm{P}<0.04, \mathrm{n}=34)$. In general, on a quadrat-base, the correlation in richness becomes stronger at the ecoregional level as compared to the country level except in the northern Atacama desert where no relationship was found (Pearson's $\mathrm{r}=0.27, \mathrm{P}>0.05, \mathrm{n}=$ 28) and in the southern subantarctic forest, which exhibits a negative relationship between taxa (Pearson's $\mathrm{r}=-0.31, \mathrm{P}<0.05, \mathrm{n}=109$ ). Pearson's correlation coefficients are highest in the Puna highland $(\mathrm{r}=0.86, \mathrm{P}<0.001, \mathrm{n}=60)$, followed by the Mediterrranean region and temperate forest with $\mathrm{r}=0.81(\mathrm{n}=59, \mathrm{P}<$ $0.001)$ and $\mathrm{r}=0.59(\mathrm{n}=79, \mathrm{P}<0.01)$ respectively.

\section{Environmental influence}

Per quadrat based pairwise correlations between species richness and environmental variables, identify NDVI as the variable that best correlates with species richness variability for both taxa, it also shows that the importance of variables rank similarly for both taxa. NDVI has the highest coefficient value, followed by the number of vegetation types (VEG) (Table 1A). However, when the analysis is performed per latitudinal bands a different order of importance arises. NDVI still shows to be the factor that correlates strongest with richness and MDE becomes important only after VEG for butterflies and is not significant at all for mammals (Table 1B).

As in the pairwise rank correlation, the multiple regression analysis at the country level, shows that NDVI is the variable that mostly affects species richness in both taxa (Table 2A). However, different models, with different explanatory power, are obtained through this procedure. The most apparent difference lies in the role of precipitation (PP), which negatively affects butterflies richness while it does not significantly affect mammal richness. For butterflies GLA is important, but for mammals elevation is more important than GLA.

The selected model for butterfly richness has a high explanatory power $\left(\mathrm{R}^{2}=0.695\right)$ as compared to the model that best explains

TABLE 1

Pairwise Pearson correlation coefficients between species richness and environmental/spatial variables; n.s. $=$ not statistically significant; $()=.\mathrm{P}<0.1,(*)=\mathrm{P}<0.01,(* *)=\mathrm{P}<0.001$, $(* * *)=\mathrm{P}<0.0001$

Coeficientes de correlación de Pearson entre riqueza de especies y variables ambientales/espaciales; $\mathrm{n} . \mathrm{s} .=$ diferencias estadísticamente no significativas; $()=.\mathrm{P}<0,1 ;(*)=\mathrm{P}<0,01 ;(* *)=\mathrm{P}<0,001 ;(* * *)=\mathrm{P}<0,0001$

\begin{tabular}{|c|c|c|c|c|}
\hline & \multicolumn{2}{|c|}{ Mammals } & \multicolumn{2}{|c|}{ Butterflies } \\
\hline NDVI & 0.376 & $(* * *)$ & 0.689 & $(* * *)$ \\
\hline Number of vegetation types & 0.146 & $(* *)$ & 0.479 & $(* * *)$ \\
\hline Temperature & -0.023 & (n.s.) & 0.316 & $(* * *)$ \\
\hline Precipitation & 0.017 & (n.s.) & -0.276 & $(* * *)$ \\
\hline Elevation & 0.134 & (.) & 0.144 & (.) \\
\hline Latitude & 0.086 & (n.s.) & 0.090 & (n.s.) \\
\hline \multicolumn{5}{|c|}{ (B) All Chile - per latitudinal bands $(\mathrm{n}=74)$} \\
\hline NDVI & 0.503 & $(* * *)$ & 0.767 & $(* * *)$ \\
\hline Number of vegetation types & 0.228 & (.) & 0.601 & $(* * *)$ \\
\hline Temperature & 0.480 & $(* * *)$ & 0.527 & $(* * *)$ \\
\hline Precipitation & -0.187 & (n.s.) & -0.242 & $(*)$ \\
\hline Elevation & 0.148 & (n.s.) & -0.076 & (n.s.) \\
\hline Latitude & 0.305 & $(* * *)$ & 0.161 & (n.s.) \\
\hline Mid-domai effect & 0.305 & (.) & 0.161 & $(* * *)$ \\
\hline
\end{tabular}


mammal richness $\left(\mathrm{R}^{2}=0.301\right)$, which is in agreement with the variance component analysis. When the multiple stepwise regression analysis is performed by latitudinal bands, GLA acquire high importance but only after NDVI for both mammals and butterflies. While for mammals GLA is important only after ELEV, GLA is the most important variable to explain butterfly richness after NDVI. MDE only shows a weak and negative effect in explaining richness patterns in both taxa (Table 2B).

Environmental influences on species richness among ecoregions in both taxa are summarized in Table 3. In general, species richness is affected by different factors among mammals and butterflies across ecoregions on a per quadrats-and per latitudinal bands-basis. Further, even within the same taxa, explanatory variables change in importance, direction, and identity.

In the Atacama desert, while ELEV and TEMP are the most important variables for butterfly richness, VEG is the only significant variable selected in the regression model for mammals (Table 3). In the Puna highlands mammals and butterflies share ELEV and TEMP as the variables that explain most of the richness variability. The selected model for the Mediterranean area shows TEMP as the variable with highest influence on both taxa and ELEV as the variable of second importance for butterflies only. In the southern temperate forest, mammal richness seems to be driven mostly by ELEV and NDVI, although PP has a negative influence on species richness. In this ecoregion butterflies are negatively affected by PP, ELEV and TEMP. Finally, in the subantarctic forest ecoregion, mammal and butterfly diversity is driven by TEMP and ELEV respectively. NDVI is the variable of second importance for both taxa. However, in contrast to butterflies, mammals are negatively affected by this variable. Interestingly, ELEV is not important in explaining mammal richness in the southern part of the country. When the analysis is carried out on the basis of latitudinal bands, $\mathrm{R}^{2}$ becomes higher and MDE is stronger in explaining richness in some ecoregions.

TABLE 2

Multiple stepwise regression and adjusted coefficient of multiple determination. Variables are normalized to allow comparison; $()=.\mathrm{P}<0.1,(*)=\mathrm{P}<0.01,(* *)=\mathrm{P}<0.001,(* * *)=\mathrm{P}<0.0001$

Regresión múltiple paso a paso y coeficiente de determinación ajustado. Las variables han sido normalizadas para permitir su comparación; $()=.\mathrm{P}<0,1 ;(*)=\mathrm{P}<0,01 ;(* *)=\mathrm{P}<0,001 ;(* * *)=\mathrm{P}<0,0001$

\begin{tabular}{lcccc}
\hline & \multicolumn{2}{c}{ Mammals } & \multicolumn{2}{c}{ Butterflies } \\
\hline (a) All Chile - per quadrats $(\mathrm{n}=34)$ & \multicolumn{2}{c}{$\left(\mathrm{R}^{2}=0.301\right)$} & \multicolumn{2}{c}{$\left(\mathrm{R}^{2}=0.695\right)$} \\
Intercept & 9.776 & $(* * *)$ & 18.928 & $(* * *)$ \\
NDVI & 4.025 & $(* * *)$ & 11.994 & $(* * *)$ \\
Elevation & 3.033 & $(* * *)$ & 3.420 & $(* * *)$ \\
Precipitation & & & -6.618 & $(* * *)$ \\
Glaciation & 1.760 & $(* * *)$ & 7.186 & $(* * *)$ \\
Number of vegetation type & -0.615 & $(* *)$ & 1.892 & $(* * *)$ \\
& & & & $\left(\mathrm{R}^{2}=0.778\right)$ \\
(b) All Chile - per latitudinal band $(\mathrm{n}=76)$ & $\left(\mathrm{R}^{2}=0.535\right)$ & & \\
Intercept & 13.819 & $(* * *)$ & 22.669 & $(* * *)$ \\
NDVI & 5.039 & $(* * *)$ & 13.206 & $(* * *)$ \\
Elevation & 2.016 & $(* * *)$ & 4.318 & $(* * *)$ \\
Precipitation & -1.139 & $(* *)$ & -3.318 & $(* * *)$ \\
Temperature & -0.303 & $()$. & & \\
Mid-domain effect & -1.145 & $(* *)$ & & \\
\hline
\end{tabular}


TABLE 3

Per quadrat based multiple stepwise regression by ecoregions; $n . s .=$ not statistically significant; $()=.\mathrm{P}<0.1,(*)=\mathrm{P}<0.01,(* *)=\mathrm{P}<0.001,(* * *)=\mathrm{P}<0.0001$

Regresión múltiple paso a paso por ecorregión; n.s. = diferencias estadísticamente no significativas; $()=.\mathrm{P}<0,1 ;(*)=\mathrm{P}<0,01 ;(* *)=\mathrm{P}<0,001 ;(* * *)=\mathrm{P}<0,0001$

\begin{tabular}{|c|c|c|c|c|}
\hline & \multicolumn{2}{|c|}{ Mammals } & \multicolumn{2}{|c|}{ Butterflies } \\
\hline North-Atacama desert $(\mathrm{n}=28)$ & \multicolumn{2}{|c|}{$\left(\mathrm{R}^{2}=0.693\right)$} & \multicolumn{2}{|c|}{$\left(\mathrm{R}^{2}=0.532\right)$} \\
\hline Intercept & 3.897 & $(* * *)$ & 12.172 & $(* * *)$ \\
\hline NDVI & -0.436 & (n.s.) & & \\
\hline Number of vegetation types & 2.100 & $(* * *)$ & & \\
\hline Temperature & & & 6.356 & $(* * *)$ \\
\hline Precipitation & 0.401 & (n.s.) & & \\
\hline Elevation & & & 3.662 & \\
\hline North-Puna highland $(\mathrm{n}=60)$ & \multicolumn{2}{|c|}{$\left(\mathrm{R}^{2}=0.701\right)$} & \multicolumn{2}{|c|}{$\left(\mathrm{R}^{2}=0.709\right)$} \\
\hline Intercept & 11.426 & $(* * *)$ & 14.639 & $(* * *)$ \\
\hline NDVI & 1.337 & (n.s.) & 2.611 & $(*)$ \\
\hline Elevation & 9.903 & $(* * *)$ & 7.756 & $(* *)$ \\
\hline Temperature & 8.881 & $(* * *)$ & 8.281 & $(* * *)$ \\
\hline Precipitation & & & 2.651 & $(* *)$ \\
\hline Number of vegetation types & -1.047 & (n.s.) & -3.252 & $(* * *)$ \\
\hline Central-Mediterranean $(\mathrm{n}=59)$ & \multicolumn{2}{|c|}{$\left(\mathrm{R}^{2}=0.542\right)$} & \multicolumn{2}{|c|}{$\left(\mathrm{R}^{2}=0.880\right)$} \\
\hline Intercept & 11.557 & $(* * *)$ & 28.344 & $(* * *)$ \\
\hline Elevation & - & & 14.401 & $(* * *)$ \\
\hline Temperature & -4.622 & $(* * *)$ & -18.035 & $(* * *)$ \\
\hline Number of vegetation types & 1.329 & $(*)$ & 4.667 & $(* * *)$ \\
\hline NDVI & 2.438 & $(* * *)$ & 5.377 & $(* * *)$ \\
\hline Precipitation & 0.160 & $(* *)$ & -3.564 & $(* * *)$ \\
\hline South-temperate forest $(n=79)$ & \multicolumn{2}{|c|}{$\left(\mathrm{R}^{2}=0.507\right)$} & \multicolumn{2}{|c|}{$\left(\mathrm{R}^{2}=0.735\right)$} \\
\hline Intercept & 14.150 & $(* * *)$ & 39.313 & $(* * *)$ \\
\hline NDVI & 2.240 & $(* *)$ & & \\
\hline Precipitation & -1.157 & $(*)$ & -8.329 & $(* * *)$ \\
\hline Elevation & 2.961 & $(* *)$ & -4.402 & $(* * *)$ \\
\hline Temperature & 0.978 & (n.s.) & -2.654 & $(* *)$ \\
\hline Number of vegetation types & -0.929 & $(* *)$ & -1.957 & $(* * *)$ \\
\hline Subantarctic forest $(\mathrm{n}=109)$ & \multicolumn{2}{|c|}{$\left(\mathrm{R}^{2}=0.298\right)$} & \multicolumn{2}{|c|}{$\left(\mathrm{R}^{2}=0.543\right)$} \\
\hline Intercept & 8.354 & $(* * *)$ & 11.664 & $(* * *)$ \\
\hline NDVI & -1.284 & $(*)$ & 2.881 & $(* * *)$ \\
\hline Precipitation & 1.064 & $(*)$ & -1.655 & $(* * *)$ \\
\hline Elevation & & & 3.255 & $(* * *)$ \\
\hline Temperature & 2.616 & $(* * *)$ & 1.671 & $(* *)$ \\
\hline Number of vegetation types & -1.229 & $(* *)$ & 1.540 & $(* * *)$ \\
\hline
\end{tabular}




\section{Variation partitioning}

Figure 3 illustrates the partition of variance in species richness among different components. This figure shows that purely spatial component do not have a major importance in driving species richness patterns in either taxa. Shared spatial component (spatial structure and environmental factors) has a considerable importance to explain butterfly richness variability as compared to mammals (36 versus $8 \%)$. On the other hand, the environmental component weight similarly for butterflies (45 $\%)$ and mammals (40\%). Among the explained fraction, the environmental is the most important for both taxa. However, for mammals $49 \%$ of the variance remains unexplained.

\section{DISCUSSION}

The study of the spatial distribution of species richness and the processes that originates it is a complex task because of the difficulties in differentiating historical from ecological processes (Ricklefs \& Schluter 1993, Hawkins \& Porter 2003b, Harrison \& Grace 2007,
Thomas et al. 2008). We have shown the existence of a strong taxonomic covariance between mammals and butterflies species richness in Chile, while no correlation would have been expected, given their physiological and life history differences.

We show that taxonomic covariation changes when assessed at different spatial scales. In particular, at the scale of latitudinal bands we find a stronger correlation between taxa than at the $0.5^{\circ}$ quadrat level. Moreover, environmental determinants for both taxa also vary with spatial scale. We hypothesize that this scale dependency emerges because at small spatial scales the presence of a species in a given site is mostly driven by individual physiology and species tolerances to local environmental conditions and ecological context. As the scale of analysis is increased, variables important at the local scale become less so, and other variables take over. While this hypothesis is not explicitly tested here, our results agree with the notion that climatic gradients are more important at large spatial scales (Hortal et al. 2008). Possibly as the result of a scale-dependent effect on individual species ranges, whereas factors related to specific ecological characteristics,

\section{(A) Mammals}

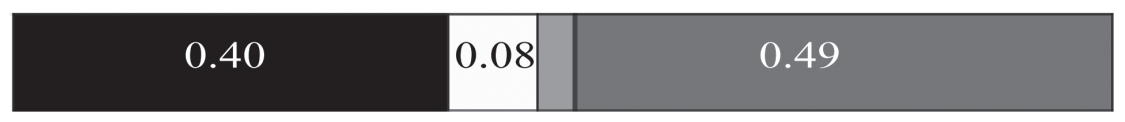

\section{(B) Butterflies}

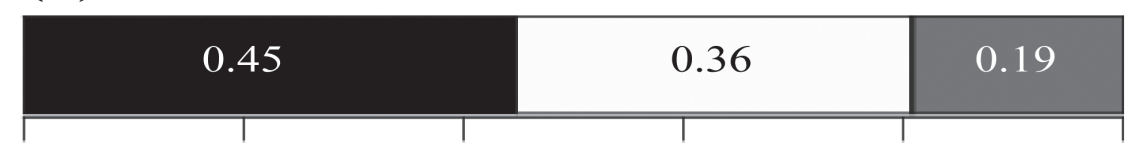
0.0
0.2
0.4
0.6
0.8
1.0

\section{environmental}

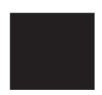

shared

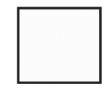

spatial

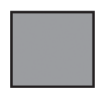

unexplained



Fig. 3: Partitioning the sources of variation in species richness. Proportion of variance that is explainable by the effect of environment (NDVI, VEG, PP, TEMP, and ELEV), space (MDE and LAT), shared by environment and space, and unexplained by none of these factors. The spatial proportion of the variance for mammals richness is of 0.034 . For butterflies, the proportion of variance explainable by space alone is 0.004 .

Partición de las fuentes de variación de la riqueza de especies. Proporción de la varianza explicable por efectos ambientales (NDVI, VEG, PP, TEMP y ELEV), espaciales (MDE y LAT), efectos compartidos entre ambientales y espaciales y por efectos no explicables por ninguno de los factores considerados. La proporción espacial de la varianza para mamíferos es de 0,034. Para mariposas, la proporción de la varianza explicada solo por el espacio es de 0,004. 
particularly those defining habitat type and biotic interactions, are more important at a smaller scale. For example, while NDVI shows to be the variable that best explains species richness at the country level, its importance is seriously challenged at smaller spatial scales where differences may partly be explained by physiological differences of each taxa (see Tables 1 and 2 versus Table 3). Similarly, within ecoregions for example, in the dry Atacama desert and Puna highlands, mammal richness seems to be mostly restricted by landscape heterogeneity and elevation respectively, while for butterflies temperature restrictions determine butterfly richness in both ecoregions. In contrast, in the southern temperate and subantarctic forest, temperature is important to mammals while precipitation and elevation seem to mostly affect butterfly richness. Finally, in the Mediterranean ecoregion, temperature seems to affect both taxa negatively. However, only butterflies are strongly, and negatively, determined by elevation.

Hence, taxon-specific differences between Chilean mammals and butterflies are unveiled at the smallest scale of analysis; large-scale richness gradients seem to be explainable by a productivity hypothesis (sensu Currie et al. 2004). Although environmental variables are the strongest correlates of richness at large scales, the history and physiographic characteristics of a region can also produce differences between the richness and their response to environmental gradients. Because richness gradients are ultimately the product of speciation and colonization processes on longer time scales, historical processes have often been ascribed to explain richness gradients of large scales (Ricklefs 1987). This is the type of explanation proposed in this research.

Several co-occurring factors may explain the observed large scale taxonomical covariation. We hypothesized that this covariation is the result of historical factors linked to glaciation events in the south and to the presence of the Atacama desert in the northern part of Chile. The main components of this hypothesis are: (1) the unique geographic distribution of Chile (narrow north-south orientation) which produces extreme environmental gradients, (2) the hyperarid conditions in the north, that constraints diversity in the lowlands and (3) the active
Pleistocene glacial history in southern temperate areas which may have induced a northward shift in the fauna and vegetation (Clapperton 1994). Clearly, these factors have interacted through time. The long-term prevalence of hyperarid conditions in the Atacama desert during the Oligocene-Miocene, that increased during Pleistocene times (Arroyo et al. 1988, Clapperton 1994, Hinojosa \& Villagrán 1997, Latorre et al. 2003, 2007), not only limited diversity because of being harsh and unproductive but also acted as a strong barrier to species migration at a time when glacial activity in the south pushed species ranges up toward northern latitudes. In this scenario, which is consistent with the significant role of glaciation in explaining diversity patterns for butterflies, the midlatitude mediterranean area, acted as a large refuge for species flanked by hyperarid conditions in the north and glacial advances in the south and the Andes mountain range to the east (Fig. 4). It is also likely that these climatic processes also fostered speciation events through different mechanisms, including repeated cycles of isolation in mountains as proposed by Fuentes \& Jaksic (1979). Similarly, Villagrán \& Hinojosa (1997) suggested glacial history as a main process accounting for the observed large number of forest plant species in Mediterranean areas. In fact, forest plant species (shrubs, vines and epiphytes) follow the same pattern as butterfly richness in Chile (see dotted line in Fig. 1B).

It is also likely that historical processes, by generating hard boundaries to species distribution (i.e., the Atacama desert in the north and Glacial advances in the south) may be associated with a MDE (Colwell \& Hurtt 1994). However, Table 2 shows that MDE is not important in explaining the observed biodiversity patterns in Chile. Null models, such as MDE, serve to establish a null hypothesis based on the action of geometric constraints only, thus if a pattern differs from the MDE expectation then other important processes might be involved (Harvey et al. 1983, Gotelli \& Graves 1996). In our case, ecological and historical processes are important at the country level.

Our analysis shows that both groups, despite sharing a common Quaternary history, are affected in their richness by different sources of 
variation. This is shown in the partition of variance analysis. The proportion of the variance in species richness explained by spatial and environmental component is highly dissimilar between taxa (Fig. 3). This is likely the result of physiological and life history differences between the two taxa. However, because mammals and butterflies differ in so many ways, it is difficult to single out a key factor that might account for these differences. Interestingly, and unlike butterflies, most variance in mammal richness is unexplained. This variance likely represents the effect of history, as we included most of the environmental variables known to be of relevance in explaining large-scale richness patterns in mammals (Currie 1991, Ruggiero \& Kitzberger 2004). Further, considering that the amount of unexplained variance in butterfly richness could be further reduced if other variables known to be associated to geographic patterns in butterfly richness were included (see below), our results suggest that historical factors may be more important in affecting richness patterns for mammals than for butterflies. This is in agreement with the greater importance of historical processes upon patterns in species richness of mammals and birds (Hawkins \& Porter 2003b) as compared to butterflies (Hawkins \& Porter 2003a). In this latter group, the more important role of spatial and environmental components of species richness reflects a higher dependence on NDVI (Table 1 and 2), which is in turn highly correlated to plant species richness (Box et al. 1989, Paruelo et al. 1998). This is reflected in the existence of a correlation between number of butterfly species and forest plant species richness in Chile (Pearson's $\mathrm{r}=0.804, \mathrm{P}<$ $0.0001, \mathrm{n}=74$ ) and is related to butterfly plant host specificity (Ehrlich \& Raven 1964, Hawkins \& Porter 2003a). However, we cannot rule out the effect of other variables known to be associated to butterfly richness patterns such as summer temperature, hours of summer sunshine, number of land cover types, number of sunny days per year or actual evapotranspiration (Turner et al. 1987, Kerr et al. 1998, 2001, Kerr 2001, Hawkins \& Porter 2003b, 2003c, Hortal et al. 2004). The analysis by ecoregions emphasizes the existence of a place and scale dependence on the factors that affect species richness. The high richness observed in the north is restricted to the Puna

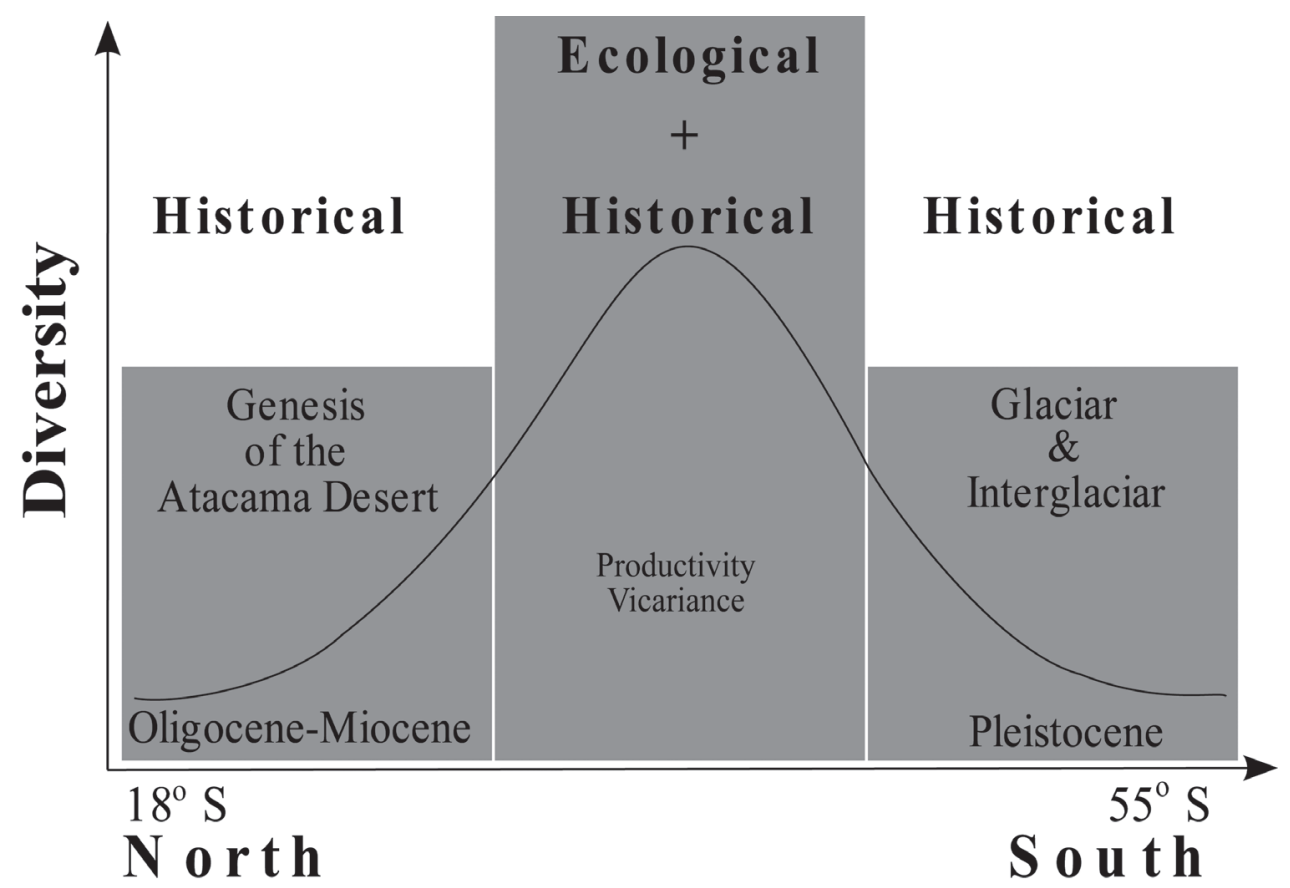

Fig. 4: Proposed model to explain latitudinal gradient of species diversity in Chile. Modelo propuesto para explicar gradiente latitudinal de diversidad de especies en Chile. 
highland, an ecoregion marginally represented in Chile that is shared with Peru, Bolivia and Argentina. This area has been described as highly vicariant, representing an active species generation center for vertebrates in general and for mammals and birds in particular (Muller 1973, Vuilleumier \& Simberloff 1980, Reig 1986). Similarly, the peak in mammal richness in this southern part of the country (Patagonia), is associated to the progressive lowering of the Andean mountain range that allow the addition of large number of faunal elements typical of the Argentinean steppe (Johnson et al. 1990). Interestingly our results are in agreement with Ruggiero \& Kitzberger (2004) at the scale of the South American continent regarding the effects of productivity.

Area effects and sampling biases have usually been invoked to explain species richness covariation (Rosenzweig 1995, Lyons \& Willig 1999, 2002). Eventhough, our quadrats decrease in area as we move southward, no significant area effect is observed when we regressed area and latitude on species richness (sensu Lyons \& Willig 1999). Sampling effect has been minimized on this dataset by the use of range distribution maps instead of sampling point distribution. This highly reduces any potential sampling biases among quadrats since butterflies and mammals are among the best known taxa in Chile, with a long tradition of research by many active taxonomists, biogeographers and ecologists (Mann 1978, Redford \& Eisenberg 1992, Jaksic 1996, Peña \& Ugarte 1996, Simonetti et al. 1996, Muñoz \& Yáñez 2000), not to mention their economic importance as pests, which has made them to become well known in terms of their distribution within the country (e.g., Artigas 1994a, 1994b).

\section{Implications for conservation}

The effective understanding of the processes involved in the spatial distribution of biodiversity imposes a growing challenge as we build up in the understanding of the implacable consequences of global change (Kareiva et al. 1993, Mooney et al. 1993). Our results together with those of Arroyo \& Cavieres (1997), Armesto et al. (1998), among others and in particular those of Myers et al. (2000), who includes central Chile as one of the most important areas of high richness to protect biodiversity at a global scale, underscores the paramount importance of south-central Chile for biological diversity. Paradoxically, this is the least protected part of the country. Currently, Chile protects roughly a $20 \%$ of its territory (Tognelli et al. 2008). However, less than $5 \%$ of the Mediterranean area is currently protected (Valencia et al. 1987, Pauchard \& Villarroel 2002, Armesto et al.1998). Despite the efforts that have been made in order to apply basic scientific knowledge to improve the protection of natural habitats (Pressey et al. 1996, Rodríguez \& Rojas-Suárez 1996, Simberloff 1998, Cofré \& Marquet 1999, Cornelius et al. 2001, Cavieres et al. 2002, Pauchard \& Villarroel 2002, Oltremari \& Thelen 2003, Tognelli et al. 2008), there is no single recipe for success. Our results, suggest that because of the existence of strong taxonomic covariation in richness patterns, the creation of a large network of protected areas between $27-35^{\circ} \mathrm{S}$ is likely to assure the conservation of a large portion of Chile's biodiversity.

\section{AKNOWLEDGMENTS}

This research was supported through a John E. Fogarty action in building capacity training grant awarded to HS, NSF biocomplexity grant DEB-0083422 and through grant FONDAP FONDECYT 1501-0001, ICM P05-002, PFB23 CONICYT, Chile. PAM was a sabbatical Fellow at NCEAS a center funded by NSF (Grant DEB-0072909), the University of California and the Santa Barbara campus.

\section{LITERATURE CITED}

ARITA HT, JG ROBINSON \& KH REDFORD (1990) Rarity in neotropical forest mammals and its ecological correlates. Conservation Biology 4: 181192.

ARITA HT, F FIGUEROA, A FRISH, P RODRÍGUEZ \& K SANTOS-DEL-PRADO (1997) Geographical range size and the conservation of Mexican mammals. Conservation Biology 11: 92-100.

ARMESTO JJ, R ROZZI, C SMITH-RAMÍREZ \& MTK ARROYO (1998) Conservation targets in South American temperate forest. Science 282: 12711272.

ARMESTO JJ, C VILLAGRÁN \& MTK ARROYO (1995) Ecología de los bosques nativos de Chile. Editorial 
Universitaria, Universidad de Chile, Santiago, Chile. 488 pp.

ARROYO MTK (1994) Ecology and biogeography of Mediterranean ecosystems in Chile, California and Australia. Springer-Verlag, Berlin, Germany. 455 pp.

ARROYO MTK \& L CAVIERES (1997) The mediterranean type-climate flora of central Chile What do we know and how can we assure it protection? Noticiero de Biología (Chile) 5: 8-56.

ARROYO MTK, FA SQUEO, JJ ARMESTO \& C VILLAGRÁN (1988) Effect of aridity on plant diversity in the northern Chilean andes: results of a natural experiment. Annals of the Missouri Botanical Garden (USA) 75: 55-78.

ARTIGAS JN (1994a) Etomología económica, insectos de interés agrícola, forestal, médica y veterinarios (nativos, introducidos y que pueden ser introducidos). Volumen 1. Ediciones de la Universidad de Concepción, Concepción, Chile. $1126 \mathrm{pp}$.

ARTIGAS JN (1994b) Etomología económica, insectos de interés agrícola, forestal, médica y veterinarios (Nativos, introducidos y que pueden ser introducidos). Volumen 2. de la Universidad de Concepción, Concepción, Chile. 943 pp.

BOKMA F, J BOKMA \& M MÖNKKÖNEN (2001) Random processes and geographic species richness patterns: why so few species in the north? Ecography 24: 43-49.

BORCARD D, P LEGENDRE \& P DRAPEAU (1992) Partialling out the spatial component of ecological variation. Ecology 73: 1045-1055.

BOX EO, BN HOLBEN \& V KALB (1989) Accuracy of the AVHRR vegetation index as a predictor of biomass, primary productivity and net $\mathrm{CO}_{2}$ flux. Vegetatio 80: 71-89.

BROWN JH \& MK LOMOLINO (1998) Biogeography. Second edition. Sinauer, Sunderland, Massachussets, USA. 691 pp.

CABRERA AL \& A WILLINK (1973) Biogeografía de América Latina. Organización de Estados Americanos, Washington, District of Columbia, USA. $120 \mathrm{pp}$.

CAVIERES LA, MTK ARROYO, P POSADAS, C MARTICORENA, O MATTHEI, R RODRÍGUEZ, FA SQUEO \& G ARANCIO (2002) Identification of priority areas for conservation in an arid zone: application of parsimony analysis of endemicity in the vascular flora of the Antofagasta region, northern Chile. Biodiversity and conservation 11: 1301-1311.

CEBALlOS G \& D NAVARRO (1991) Diversity and conservation of Mexican mammals. In: Mares MA \& DJ Schmidly (eds) Latin American mammalogy: history, biodiversity, and conservation: 167-198. The University of Oklahoma Press, Norman, Oklahoma, USA.

CLAPPERTON C (1994) The quaternary glaciation of Chile: a review. Revista Chilena de Historia Natural 67: 369-383.

COFRÉ HL \& PA MARQUET (1999) Conservation status, rarity, and geographic priorities for conservation of Chilean mammals: an assessment. Biological Conservation 88: 53-68.

COFRÉ HL, H SAMANIEGO \& PA MARQUET (2007) Rarity and richness patterns of small mammals in mediterranean and temperate Chile. In: Kelt DA, EP Lessa, J Salazar-Bravo \& JL Patton (eds) The quintessential naturalist: honoring the life and legacy of Oliver P. Pearson: 275-302. University of California Publications in Zoology, California, USA.

COLWELL RK \& GC HURTT (1994) Nonbiological gradients in a species richness and a spurious rapoport effect. American Naturalist 144: 570-595.

COLWELL RK \& DC LEES (2000) The mid-domain effect: geometric constraints on the geography of species richness. Trends in Ecology and Evolution 15: 70-76.

COLWELL RK, C RAHBEK \& NJ GOTELLI (2005) The mid-domain effect: there's a baby in the bathwater. American Naturalist 166: E149-E154.

CONCHA-BLOOMFIELD I \& L PARRA (2007) Análisis cualitativo y cuantitativo de la diversidad de mariposas de la estación biológica Senda Darwin, Chiloé, X Región, Chile. Gayana (Chile) 70: 186194.

CORNELIUS C, SA NAVARRETE \& PA MARQUET (2001) Effects of human activity on the structure of coastal marine bird assemblages in central Chile. Conservation Biology 15: 1396-1404.

CURRIE DJ (1991) Energy and large-scale patterns of animal- and plant-species richness. American Naturalist 137: 27-49.

CURRIE DJ, GG MITTELBACH, HV CORNELL, R FIELD, JF GUEGAN, BA HAWKINS, DM KAUFMAN, JT KERR, T OBERDORFF, E O'BRIEN \& JRG TURNER (2004) Predictions and tests of climate-based hypotheses of broad-scale variation in taxonomic richness. Ecology Letters 7: 1121-1134.

CURRIE DJ \& V PAQUIN (1987) Large-scale biogeographical patterns of species richness of trees. Nature 329: 326-327.

DOBSON AP, JP RODRÍGUEZ, WM ROBERTS \& DS WILCOVE (1997) Geographic distribution of endangered species in the United States. Science 275: 550-553.

EHRLICH PR \& PH RAVEN (1964) Butterflies and plants: a study in coevolution. Evolution 18: 586608.

FJELDSA J, D EHRLICH, E LAMBIN \& E PRINS (1997) Are biodiversity 'hotspots' correlated with current ecoclimatic stability? A pilot study using the NOAA-AVHRR remote sensing data. Biodiversity and Conservation 6: 401-422.

FLATHER CH, KR WILSON, DJ DEAN \& WC McCOMB (1997) Identifying gaps in conservation networks: of indicators and uncertainty in geographic-based analysis. Ecological Applications 7: 531-542.

FUENTES ER \& FM JAKSIC (1979) Lizards and rodents: an explanation for their relative species diversity in Chile. Archivos de Biología y Medicina Experimentales (Chile) 12: 179-190.

GAJARDO R (1994) La vegetación natural de Chile: clasificación y distribución geográfica. Editorial Universitaria, Santiago, Chile. 165 pp.

GASTON KJ (1996) Species-range-size distribution: patterns, mechanisms and implications. Trends in Ecology and Evolution 11: 197-201.

GASTON KJ (2000) Global patterns in biodiversity. Nature 405: 220-227.

GOTELLI N \& G GRAVES (1996) Null models in ecology. Smithsonian Institution Press, Washington, District of Columbia, USA. 368 pp.

HAJEK ER \& F DI CASTRI (1975) Bioclimatología de Chile. Ediciones de la Universidad Católica de Chile, Santiago, Chile. 129 pp.

HARRISON S \& JB GRACE (2007) Biogeographic 
affinity helps explain productivity-richness relationships at regional and local scales. American Naturalist 170: S5-S15.

HARVEY P, R COLWELL, J SILVERTOWN \& R MAY (1983) Null models in ecology. Annual Review of Ecology and Systematics 14: 189-211.

HAWKINS B, JAF DINIZ-FILHO \& A WEIS (2005) The mid-domain effect and diversity gradients: is there anything to learn? American Naturalist 166: E140E143.

HAWKINS BA \& EE PORTER (2003a) Does herbivore diversity depend on plant diversity? the case of California butterflies. American Naturalist 161: 40-49.

HAWKINS BA \& EE PORTER (2003b) Relative influences of current and historical factors on mammal and bird diversity patterns in deglaciated North America. Global Ecology and Biogeography 12: 475-481.

HAWKINS BA \& EE PORTER (2003c) Water-energy balance and the geographic pattern of species richness of western Palearctic butterflies. Ecological Entomology 28: 678-686.

HINOJOSA L \& C VILLAGRÁN (1997) Historia de los bosques de Sudamérica I: el Terciario. Revista Chilena de Historia Natural 70: 221-224.

HOLLIN JT \& DH SCHILLING (1981) Late WisconsinWeichselian mountain glaciers and small ice caps In: Denton GH \& TJ Hughes (eds) The last great ice sheets: 179-206. John Wiley, New York, USA.

HORTAL J, P GARCIA-PEREIRA \& E GARCÍABARROS (2004) Butterfly species richness in mainland portugal: predictive models of geographic distribution patterns. Ecography 27: 68-82.

HORTAL J, J RODRÍGUEZ, M NIETO-DÍAZ \& JM LOBO (2008) Regional and environmental effects on the species richness of mammal assemblages. Journal of Biogeography 35: 1202-1214.

HURLBERT AH \& JP HASKELL (2003) The effect of energy and seasonality on avian species richness and community composition. American Naturalist 161: 83-97.

JAKSIC F (1996) Ecología de los vertebrados de Chile. Ediciones Universidad Católica de Chile, Santiago, Chile. $262 \mathrm{pp}$

JETZ W \& C RAHBEK (2001) Geometric constraints explain much of the species richness pattern in African birds. Proceedings of the National Academy of Sciences USA 98: 5661-5666.

JETZ W \& C RAHBEK (2002) Geographic range size and determinants of avian species richness. Science 297: 1548-1551.

JOHNSON WE, WL FRANKLIN \& IJ A (1990) The mammalian fauna of the northern Chilean Patagonia: a biogeographical dilemma. Mammalia 54: 457-469.

KAREIVA P, JG KINGSOLVER \& RB HUEY (1993) Biotic interactions and global change. Sinauer Associates, Sunderland, Massachusetts, USA. 559 pp.

KELT DA \& MH GALLARDO (1994) A new species of tuco-tuco, genus Ctenomys (Rodentia: Ctenomyidae) from Patagonian Chile. Journal of Mammalogy 75: 338-348

KERR JT \& L PACKER (1997) Habitat heterogeneity as a determinant of mammal species richness in highenergy regions. Nature 385: 252-254.

KERR JT, R VINCENT \& DJ CURRIE (1998) Lepidopteran richness patterns in North America. Ecoscience 5: 448-453.

KERR JT \& DJ CURRIE (1999) The relative importance of evolutionary and environmental controls on broad-scale patterns of species richness in North America. Ecoscience 6: 329-337

KERR JT \& L PACKER (1999) The environmental basis of North American species richness patterns among Epicauta (Coleoptera: Meloidae). Biodiversity and Conservation 8: 617-628.

KERR JT (2001) Butterfly species richness patterns in Canada: energy, heterogeneity, and the potential consequences of climate change. Conservation Ecology 5: 10 .

KERR JT, TRE SOUTHWOOD \& J CIHLAR (2001) Remotely sensed habitat diversity predicts butterfly species richness and community similarity in Canada. Proceedings of the National Academy of Sciences USA 98: 11365-11370.

KERR JT \& M OSTROVSKY (2003) From space to species: ecological applications for remote sensing. Trends in Ecology \& Evolution 18: 299-305.

KERR JT, M PERRING \& DJ CURRIE (2006) The missing Madagascan mid-domain effect. Ecology Letters 9: 149-159.

LATHAM RE \& RE RICKLEFS (1993) Global patterns of tree species richness in moist forest: energydiversity theory does not account for variation in species richness. Oikos 67: 325-333.

LATORRE C, JL BETANCOURT, KA RYLANDER, J QUADE \& O MATTHEI (2003) A vegetation history from the arid prepuna of northern chile (22$23^{\circ} \mathrm{S}$ ) over the last 13500 years. Palaeogeography, Palaeoclimatology \& Palaeoecology 194: 223-246.

LATORRE C, PI MORENO, G VARGAS, A MALDONADO, $\mathrm{R}$ VILLA-MARTÍNEZ, JJ ARMESTO, C VILLAGRÁN, M PINO, L NÚÑEZ \& M GROSJEAN (2007) Late Quaternary environments and paleoclimate. In: Gibbons W \& T Moreno (eds) The Geology of Chile: 309-328. London Geological Society Press, London, UK.LEGENDRE P (1993) Spatial autocorrelation: trouble or new paradigm? Ecology 74: 1659-1673.

LEGENDRE P \& L LEGENDRE (1998) Numerical ecology. Second edition. Elsevier Science, Amsterdam, The Nethenlands. $853 \mathrm{pp}$.

LOBO JM, JP LUMARET \& P JAY-ROBERT (2002) Modelling the species richness distribution of French dung beetles (Coleoptera, Scarabaeidae) and delimiting the predictive capacity of different groups of explanatory variables. Global Ecology and Biogeography 11: 265-277.

LYONS SK \& MR WILLIG (1999) A hemispheric assessment of scale dependence in latitudinal gradients of species richness. Ecology 80: 24832491.

LYONS SK \& MR WILLIG (2002) Species richness, latitude, and scale-sensitivity. Ecology 83: 47-58.

MANN G (1978) Los pequeños mamíferos de Chile. Gayana Zoología (Chile) 40: 1-342.

MARQUET PA (1994) Diversity of small mammals in the pacific coastal desert of Peru and Chile and in the adjacent area: biogeography and community structure. Australian Journal of Zoology 42: $527-$ 542 .

MARQUET P, M FERNÁNDEZ, S NAVARRETE \& C VALDOVINOS (2004) Diversity energing: toward a deconstruction of diversity patterns In: Lomolino MV \& LR Heaney (eds) Frontiers of biogeography: new directions in the geography of nature: 191-209 Cambridge University Press, Cambridge, United Kingdom.

MARQUET PA, F BOZINOVIC, G BRADSHAW, C 
CORNELIUS, H GUTIÉRREZ, ER HAJEK, JA LAGOS, F LÓPEZ-CORTÉS, L NÚÑEZ, EF ROSELLO, C SANTORO, H SAMANIEGO, VG STANDEN, JC TORRES-MURA \& JAKSIC (1998) Los ecosistemas del desierto de Atacama y área andina adyacente en el norte de Chile. Revista Chilena de Historia Natural 71: 593-617.

McCAIN CM (2005) Elevational gradients in diversity of small mammals. Ecology 86: 366-372.

McCLAIN CR, EP WHITE \& AH HURLBERT (2007) Challenges in the application of geometric constraint models. Global Ecology and Biogeography 16: 257-264.

McCOY E \& E CONNOR (1980) Latitudinal gradients in the species diversity of North American mammals. Evolution 34: 193-203

MEDEL RG, JE JIMÉNEZ, FM JAKSIC, JL YÁÑEZ \& JJ ARMESTO (1990) Discovery of a continental population of trhe rare Darwin fox, Dusicyon fulvipes (martin, 1837) in Chile. Biological Conservation 51: 71-77.

MOONEY HA, ER FUENTES \& BI KRONBERG (1993) Earth system responses to global change: contrast between North and South America. Academic Press, New York, USA. 365 pp.

MORENO P, C VILLAGRÁN, P MARQUET \& L MARSHALL (1994) Quaternary paleobiogeography of northern and central Chile. Revista Chilena de Historia Natural 67: 487-502.

MUÑOZ A \& J YÁÑEZ (2000) Mamíferos de Chile. CEA Ediciones, Valdivia, Chile. $460 \mathrm{pp}$.

MÜLLER P (1973) The dispersal centres of terrestrial vertebrates in the neotropical realm. A study in the evolution of the Neotropical biota and its native landscapes. Dr W Junk, The Hague, The Netherlands. 244 pp.

MYERS N, R MITTERMEIER, G DA FONSECA \& J KENT (2000) Biodiversity hotspots for conservation priorities. Nature 403: 853-858.

NICHOLS WF, KT KILLINGBECK \& PV AUGUST (1998) The influence of geomorphological heterogeneity on biodiversity. II. A landscapes perspective. Conservation Biology 12: 371-379.

OESTERHELD M, CM DIBELLA \& H KERDILES (1998) Relation between NOAA-AVHRR satellite data and stocking rate rangelands. Ecological Applications 8: 207-212.

OLTREMARI JV \& KD THELEN (2003) Evolution of the planning process for protected areas in Latin America. Natural Areas Journal 23: 174-179.

PARUELO JM, EG JOBBAGY, OE SALA, WK LAUEROTH \& IC BURKE (1998) Functional and structural convergence of temperate grassland and shrubland ecosystems. Ecological Applications 8: 194-206.

PAUCHARD A \& P VILLARROEL (2002) Protected areas in Chile: history, current status, and challenges. Natural Areas Journal 22: 318-330.

PEÑA LE \& AJ UGARTE (1996) Mariposas de Chile. Editorial Universitaria, Santiago, Chile. 360 pp.

PEARSON DL \& F CASSOLA (1992) World-wide species richness patterns of tiger beetles (Coleoptera, Cicindelidae) - indicator taxon for biodiversity and conservation studies. Conservation Biology 6: 376391.

PRENDERGAST JR, RM QUINN, JH LAWTON, BC EVERSHAM \& DW GIBBONS (1993) Rare species, the coincidence of diversity hotspots and conservation strategies. Nature 365: 335-337.

PRESSEY R, CJ HUMPHRIES, C MARGULES, RI VAN-
WRIGHT \& PH WILLIAMS (1993) Beyond opportunism: key principles for systematic reserve selection. Trends in Ecology and Evolution 8: 124128.

PRESSEY RL, HP POSSINGHAM \& CR MARGULES (1996) Optimality in reserve selection algorithms: when does it matter and how much? Biological Conservation 76: 259-267.

RABINOVICH JE \& EH RAPOPORT (1975) Geographical variation of diversity in Argentine passerine birds. Journal of Biogeography 2: 141157

RAHBEK C (1997) The relation among area, elevation, and regional species richness in Neotropical birds. American Naturalist 149: 875-902.

RANGEL TFLVB \& JAF DINIZ-FILHO (2005) Neutral community dynamics, the mid-domain effect and spatial patterns in species richness. Ecology Letters 8: 783-790.

RAPOPORT EH (1975) Areografía: estrategias geográficas de las especies. Fondo de Cultura Económica, México, Distrito Federal. 215 pp.

REDFORD KH \& JK EISENBERG (1992) The mammals of the Neotropics: the southern cone of South America. University of Chicago Press, Chicago, Illinois, USA. 460 pp.

REIG O (1986) High altitude tropical biogeography. Oxford University Press, Oxford, United Kingdom.

RICKLEFS RE (1987) Community diversity: relative roles of local and regional processes. Science 235: 167171

RICKLEFS R \& D SCHLUTER (1993) Species diversity and ecological communities: historical and geographical perspectives. University of Chicago Press, Chicago, Illinois, USA. 414 pp.

RODRÍGUEZ JP \& F ROJAS-SUÁREZ (1996) Guidelines for the design of conservation strategies for the animals of Venezuela. Conservation Biology 10: $1245-1252$.

ROHDE K (1992) Latitudinal gradients in species diversity: the search of the primary cause. Oikos 65: 514-527.

ROMDAL T, R COLWELL \& C RAHBEK (2005) The influence of band sum area, domain extent, and range sizes on the latitudinal mid-domain effect. Ecology 86: 235-244.

ROOT T (1988) Energy constraints on avian distributions and abundances. Ecology 69: 330-339.

ROSENZWEIG ML (1995) Species diversity in space and time. Cambridge University Press, New York, New York, USA. 437 pp.

ROSENZWEIG ML \& EA SANDLIN (1997) Species diversity and latitude: listening to area's signal. Oikos 80: 172-176.

RUGGIERO A, JH LAWTON \& TM BLACKBURN (1998) The geographic ranges of mammalian species in South America: spatial patterns in environmental resistance and anisotropy. Journal of Biogeography 25: 1093-1103.

RUGGIERO A \& T KITZBERGER (2004) Environmental correlates of mammal species richness in South America: effects of spatial structure, taxonomy and geographic range. Ecography 27: 401-417.

SHAPIRO AM (1997) Impacto antopogénicos sobre la fauna de mariposas (Lepidoptera: Rhopalocera) de Patagonia austral y tierra del fuego. Anales del Instuto de la Patagonia (Chile) 25: 117-126.

SHMIDA A \& MV WILSON (1985) Biological determinants of species diversity. Journal of Biogeography 12: 1-20. 
SIMBERLOFF D (1998) Flagships, umbrellas, and keystones: is single-species management passe in the landscape era? Biological Conservation 83: 247 257.

SIMONETTI JA, MTK ARROYO, AE SPOTORNO \& E LOZADA (1996) Diversidad biológica de Chile. Comisión Nacional de Ciencia y Tecnología, Santiago, Chile. 364 pp

SMITH PM, SN KALLURI, SD PRINCE \& R DEFRIES (1997) The NOAA/NASA pathfinder AVHRR 8-km land data set. Photogrammetric Engineering and Remote Sensing 63: 12-32.

SPOTORNO AE, J SUFÁN-CATALÁN \& LI WALKER (1994) Cytogenetic diversity and evolution of Andean species of Eligmodontia (Rodentia, Muridae). Zeitschrift für Saugetierkunde 59: 299308.

STEVENS GC (1992) The elevation gradient in latitudinal range: an extension of Rapoport's latitudinal rule to altitude. American Naturalist 140: 893-911.

THOMAS GH, CDL ORME, RG DAVIES, VA OLSON, PM BENNETT, KJ GASTON, IPF OWENS \& TM BLACKBURN (2008) Regional variation in the historical components of global avian species richness. Global Ecology and Biogeography 17: 340-351.

TOGNELLI MF \& DA KELT (2004) Analysis of determinants of mammalian species richness in South America using spatial autoregressive models. Ecography 27: 427-436.

TOGNELLI MF, PI RAMÍREZ DE ARELLANO \& PA MARQUET (2008) How well do the existing and proposed reserve networks represent vertebrate species in Chile? Diversity and Distributions 14: 148-158.

TURNER JRG, CM GATEHUSE \& CA COREY (1987) Does solar energy control organic diversity? Butterflies, moths and the British climate. Oikos 48: 195-205.

VALENCIA J, M LÓPEZ \& M SALLABERRY (1987) Sistemas de áreas de conservación en Chile: proposiciones para un esquema ecológico integral. Ambiente y Desarrollo (Chile) 3: 139-154

VAN JAARSVELD AS, S FREITAG, SL CHOWN, C MULLER, S KOCH, H HULL, C BELLAMY, M

Associate Editor: Patricio Camus

Received February 2, 2008; accepted December 15, 2008
FRUGER, S ENDRODY-YOUNGA, MW MANSELL \& CH SCHOLTZ (1998) Biodiversity assessment and conservation strategies. Science 279: 2106-2108.

VAN RENSBURG BJ, SL CHOWN \& KJ GASTON (2002) Species richness, environmental correlates, and spatial scale: a test using South African birds. American Naturalist 159: 566-577.

VANE-WRIGHT RI (1996) Identifying priorities for conservation of biodiversity: systematic biological criteria within a socio-political framework. In: Gaston KJ (ed) Biodiversity: a biology of numbers and difference: 309-344. Blackwell Science, Oxford, United Kingdom.

VENABLES WN \& BD RIPLEY (2002) Modern applied statistics with S-PLUS. Third edition. Springer, Oxford, United Kingdom. 495 pp.

VILLAGRÁN C \& LF HINOJOSA (1997) Historia de los bosques de Sudamérica II: fitogeografía. Revista Chilena de Historia Natural 70: 241-267.

VUILLEUMIER F \& D SIMBERLOFF (1980) Ecology versus history as determinants of patchy and insular distributions in high Andean birds. Evolutionary Biology 12: 235-379

WESSELS KJ, S FREITAG \& AS VAN JAARSVELD (1999) The use of land facets as biodiversity surrogates during reserve selection at a local scale. Biological Conservation 89: 21-38.

WILLIG MG \& EA SANDLIN (1991) Gradients of species density and species turnover in new world bats: A comparison of quadrat and band methodologies. In: Mares M \& D Schmidly (eds) Latin American mammalogy: history, biodiversity, and conservation: 81-96. University of Oklahoma Press, Norman, Oklahoma, USA.

WILSON JW (1974) Analytical zoogeography of North American mammals. Evolution 28: 124-140.

WILSON DE \& DM REEDER (2005) Mammal species of the world: a taxonomic and geographic reference. Third edition. The Johns Hopkins University Press, Washington, District of Columbia, USA. 2000 pp

ZAPATA FA, KJ GASTON \& SL CHOWN (2003) Middomain models of species richness gradients: assumptions, methods and evidence. Journal of Animal Ecology 72: 677-690 
